\title{
Krigen 1864 i dansk og tysk billedkunst
}

\author{
Af INGE AdRIANSEN
}

Ved de første kunstakademier, der blev oprettet i 1600-tallet, blev historiemaleriet anset for den fornemste genre indenfor malerkunsten. Denne vurdering skyldtes de særlige krav, som en god historiemaler skulle opfylde. Ud fra historiske værker skulle han fortolke en fortidig begivenhed og omforme det til fængende billedsprog. I slutningen af 1700-tallet blev det tilladt også at skildre samtidige historiske begivenheder, og historiemaleriet kom nu i høj grad til at tjene til forherligelse af fyrstehuse og store mænds bedrifter. I slutningen af 1800-tallet svandt interessen for historiemaleriet, der dog nåede en opblomstring både i Danmark på grund af De slesvigske Krige og i Tyskland som følge af kejserrigets grundlæggelse.

\section{Indledning}

»Kunst og Poesie ere nu vort Danevirke«; således skrev H.C. Andersen i 1866 i et brev til maleren Carl Bloch. ${ }^{1}$ Digteren var blevet opildnet ved at høre om Blochs store nye historiemaleri med titel »Niels Ebbesen og Grev Gert«. Motivet med den brave jyske adelsmand, der i 1340 ikke ville lade sig undertrykke af den holstenske greve Gert og derfor slog ham ihjel, vakte begejstring hos mange, der ligesom digteren fortolkede det som et trøsterigt budskab om, at (tyske) tyranner kan bekæmpes. Historiemalerier afspejler en fortidig begivenhed set gennem et kunstnerisk temperament og ofte med en samtidshistorisk fortolkning. I mange europæiske lande blomstrede historiemaleriet i sidste halvdel af 1800-årene og var med til at styrke både gamle og nye nationer ved at belyse fælles historie og fælles myter.

I denne artikel vil der blive præsenteret en række danske og tyske historiemalerier med motiver fra 1864-krigen. Undersøgelsen sigter at afdække forskelle og ligheder på de danske og tyske historiemalerier fra denne krig, både med hensyn til valg af motiver og skildringer af kampe. Desuden søges det afklaret, hvor længe 1864-krigen var et tema, som malerne gav sig i kast med, og om der er forskelle på dette felt mellem den sejrende og den tabende nation. 
Billederne er udvalgt ved en gennemgang af værker i danske og tyske museer, især Museum Sønderjylland - Sønderborg Slot, Det Nationalhistoriske Museum på Frederiksborg Slot, Schleswig-Holsteinische Landesbibliothek, Kunsthalle zu Kiel, Museumsberg Flensburg og Deutsches Historisches Museum i Berlin. Så vidt muligt er der valgt billeder, der kan belyse hinanden. Det har været ønsket at præsentere mange billeder, i alt 23, med en kort tekst, der først og fremmest redegør for motivet og den historiske begivenhed, som det belyser.

Malerne er ikke en del af denne artikels tema, og de er derfor kun omtalt i meget begrænset grad. Billeder med symbolsk indhold, som for eksempel Carl Blochs billede, der vakte H.C. Andersens begejstring, er heller ikke medtaget, da undersøgelsen af pladshensyn må koncentrere sig om værkerne med 'faktuelle' motiver. Den stramme form med mange billeder og korte tekster har gjort det nødvendigt at fravælge enkelte billeder, hvis baggrund og virkningshistorie er for kompliceret at fortælle i den valgte form, der ikke giver plads til historiske eller ikonografiske analyser. Til gengæld forsøger artiklen at pirre læsernes interesse ved at sammenstille malerier henover landegrænsen.

Den eksisterende forskning på området er ret beskeden og består af artikler henholdsvis om dansk eller tysk historiemaleri, men hidtil er der ikke publiceret forskning, der sammenligner værker af kunstnere i de to 'fjendelande'. Tyske historiemalerier fra de tre krige 1864, 1866 og 1870-71 er grundigt belyst af Frank Becher 2001 i disputatsen Bilder von Krieg und Nation. Die Einigungskriege in der bürgerlichen Öffentlichkeit Deutschlands 1864-1913. Et tilsvarende værk over danske historiemalerier findes ikke, men der er publiceret en række artikler, især i forbindelse med særudstillinger i anledninger af et 1864-jubilæum. Frederiksborg-museet udgav ved 100-års jubilæet 1864 i danske billeder, skrevet af H.D. Schepelern, og ved 150-års jubilæet kataloget 1864. Krigen der forandrede Danmark, redigeret af Thomas Lyngby. Søren Mentz skrev i 2003 artiklen »Kunsten at fremstille en død helt. Officersportrætter fra De slesvigske krige og dansk nationalisme i slutningen af 1800-tallet«. De nyeste bidrag på tysk og dansk side er skrevet i 2014 af Bärbel Manitz, Hans Günther Andresen og Inge Adriansen og publiceret i ledsagebogen til særudstillingen Mennesker i Krigen 1864 - Menschen im Krieg, der blev vist i Kiel, Sønderborg og København. 


\section{Imposante billeder af magtens mænd}

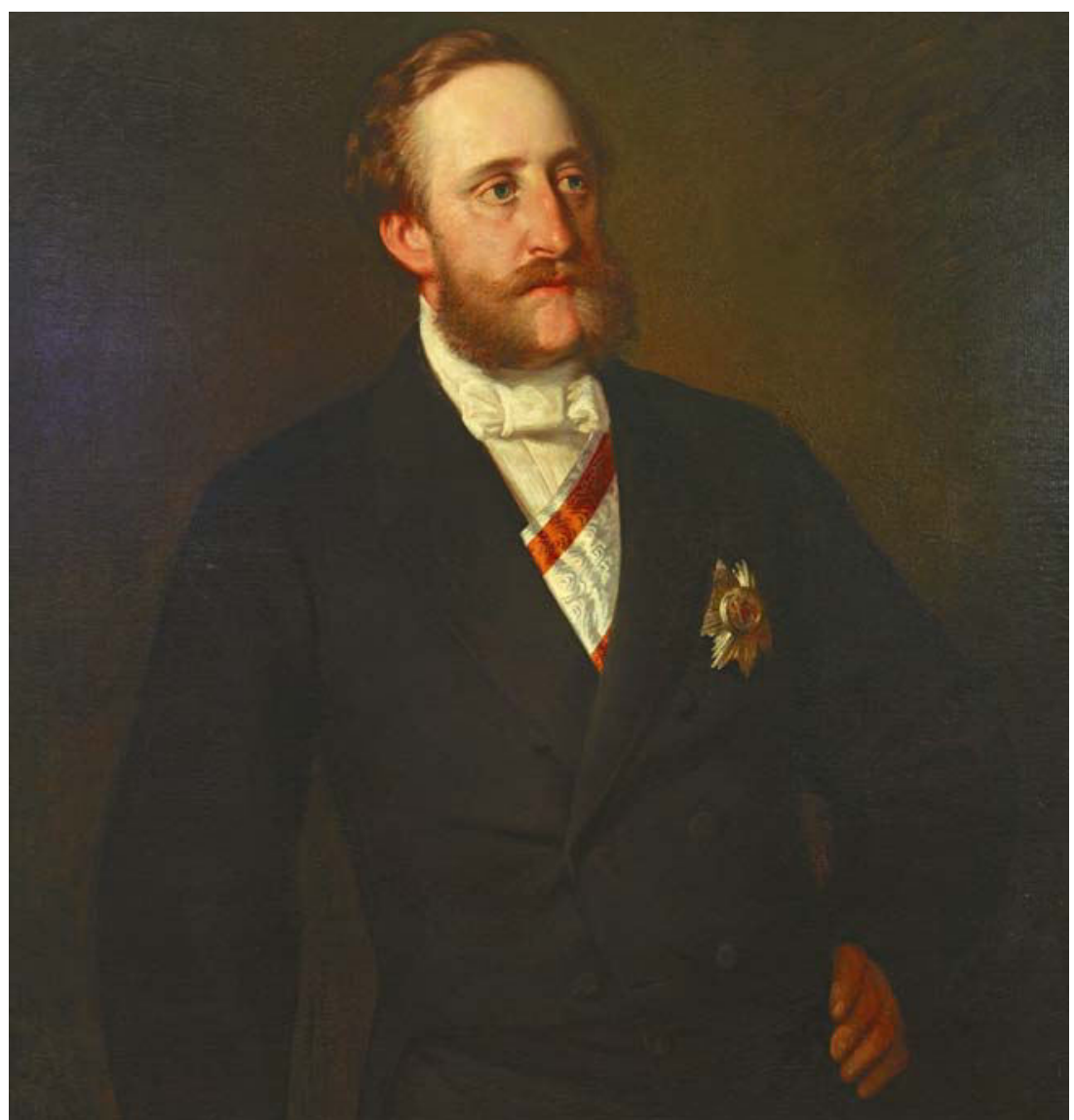

Carl Christian Magnussen: Herzog Friedrich VIII. 1863. Olie på lærred. $110 \times 86$ $\mathrm{cm}$. Kunsthalle zu Kiel. Foto: Kunsthalle.

Hertug Friedrich har ladet sig afbilde som en statsmand med ordensbånd. Han er klar til at præsentere de augustenborgske arverettigheder til Slesvig-Holsten. Selvom Friedrich er malet imposant i trekvart figur, så fremstår han ikke helt med fyrstelig værdighed, for hans ansigtstræk har anstrøg af den ubeslutsomhed, der karakteriserede hans politik og optræden. Portrættet er malet af en af hans varme tilhængere, C.C. Magnussen, i sommeren 1863 under den optrækkende krise om hertugdømmerne. 


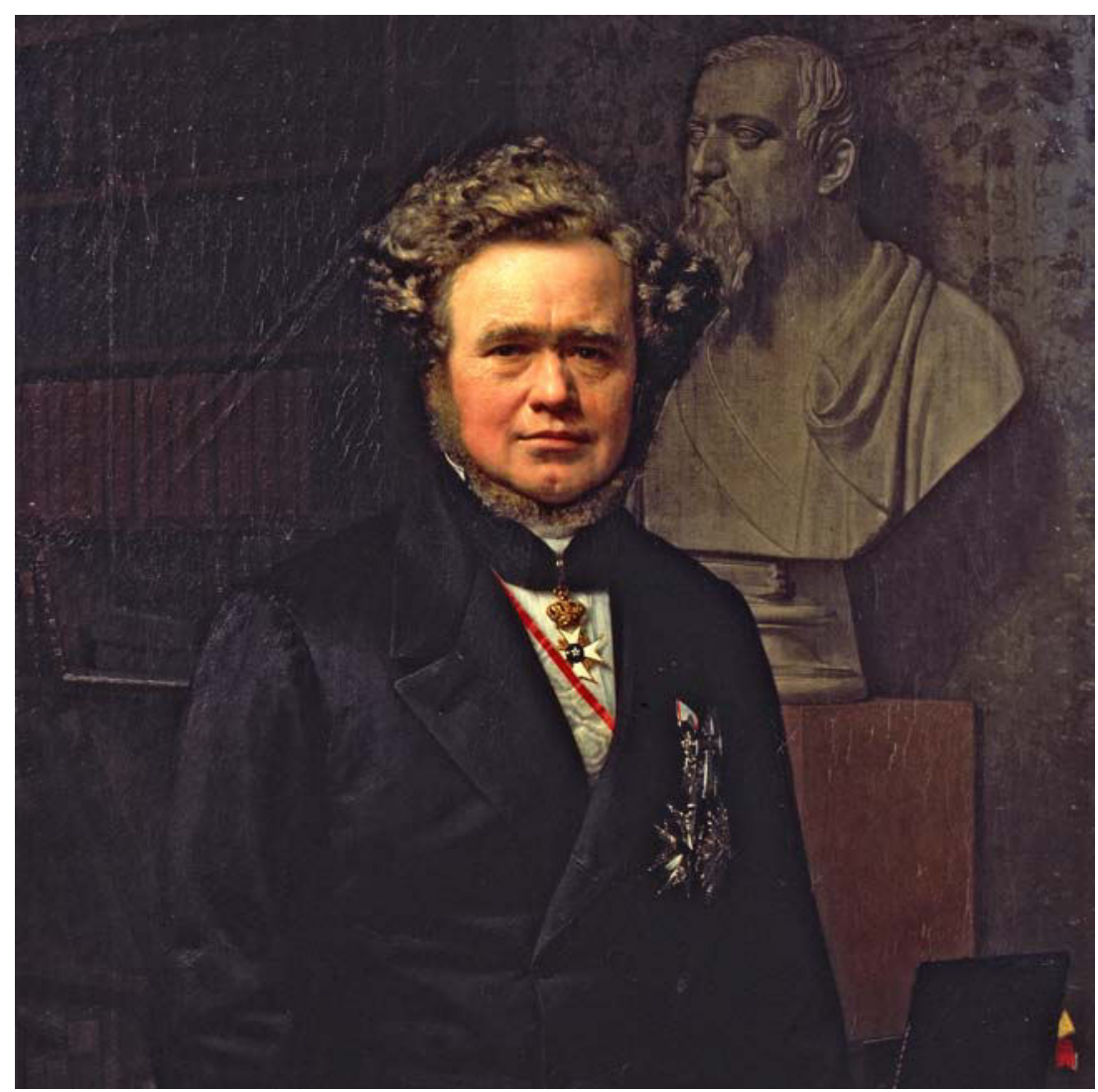

Johan Vilhelm Gertner: Carl Christian Hall. 1864. Olie på lærred. 126,5 × $88 \mathrm{~cm}$. Det Nationalhistoriske Museum på Frederiksborg Slot. Foto: Hans Petersen.

C.C. Hall var statsminister 1857 til december 1863 med en afbrydelse på nogle måneder. Han gennemførte Novemberforfatningen, der var den umiddelbare årsag til krigens udbrud, og et eksemplar af den ligger på hans bord. I baggrunden ses en buste af Frederik VII, og hermed sendes et signal om, at Hall var i overensstemmelse med sin konge, også hvad Novemberforfatningen angik. Der er stor portrætlighed, men ingen indtrængende karakteristik. Han er skildret som den arbejdsomme statsminister med dekorationer, der afspejler påskønnelse af hans indsats for fædrelandet. Billedet er udført i 1864 og kan tolkes som Halls forsøg på at sikre sit eftermæle. 


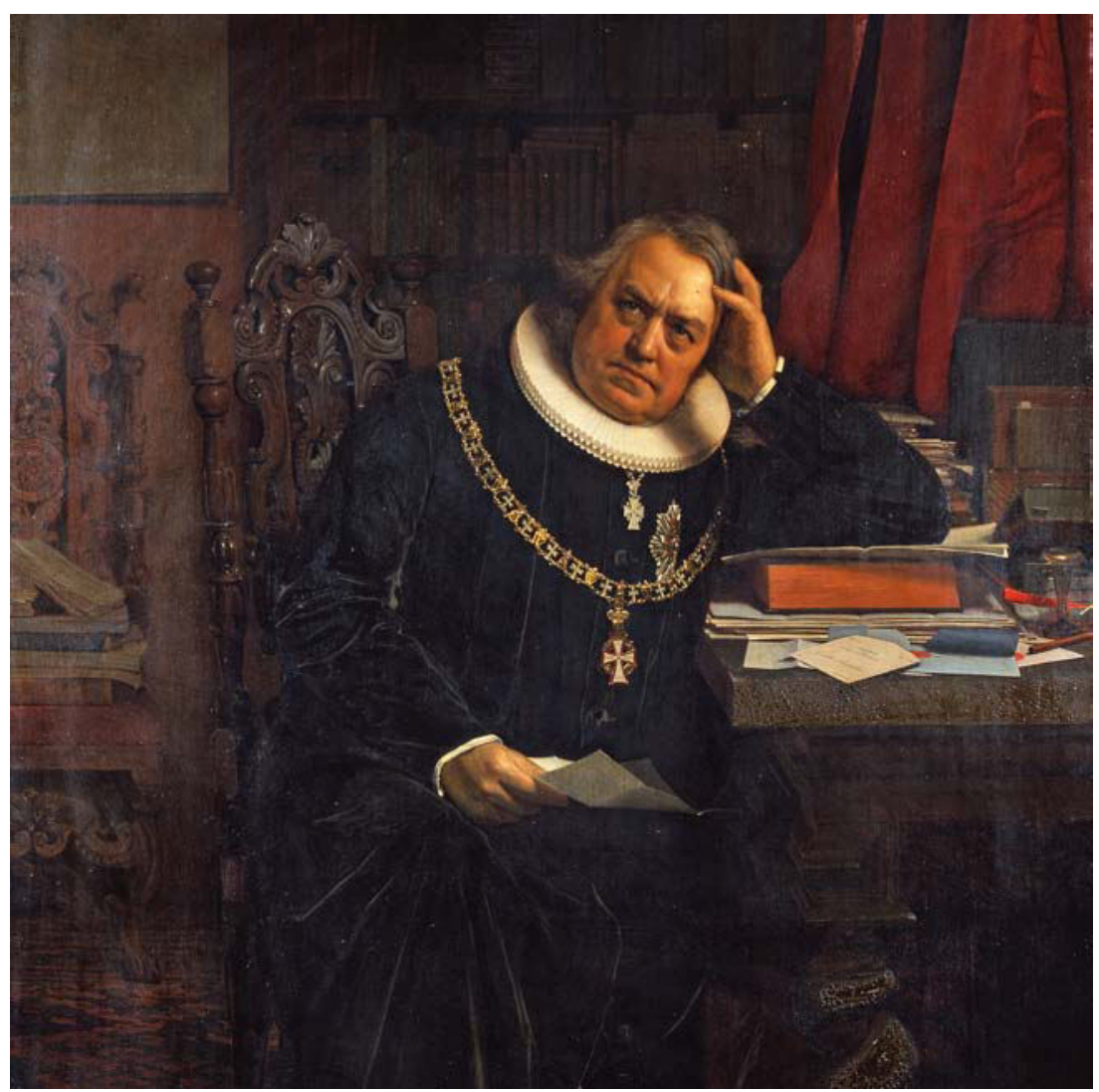

Johan Vilhelm Gertner: Ditlev Gothard Monrad. 1864. Olie på lærred. $179 \times 122,5$ cm. Det Nationalhistoriske Museum på Frederiksborg Slot. Foto: Lennart Larsen.

D.G. Monrad overtog regeringsmagten ved årsskiftet 1863/64 og trådte først tilbage efter erobringen af Als. Portrættet er ejendommeligt ved at skildre en magthaver som afmægtig. Ligesom Hall har Monrad valgt at lade sig afbilde i sit arbejdsværelse. På bordet ligger et telegram fra fredskonferencen i London, antageligt med stormagternes sidste forslag til Slesvigs deling. I hånden holder han et andet telegram, måske fra den danske delegation i London. Monrad bærer magtens ydre kendetegn. Han er iført bispekjole, uagtet at han var blevet afskediget som biskop i 1854. Hans bryst er prydet med storkorsordenen, selvom han først modtog den efter afskedigelsen som regeringschef. 


\section{De (næsten) samtidige skildringer af 1864-krigen}

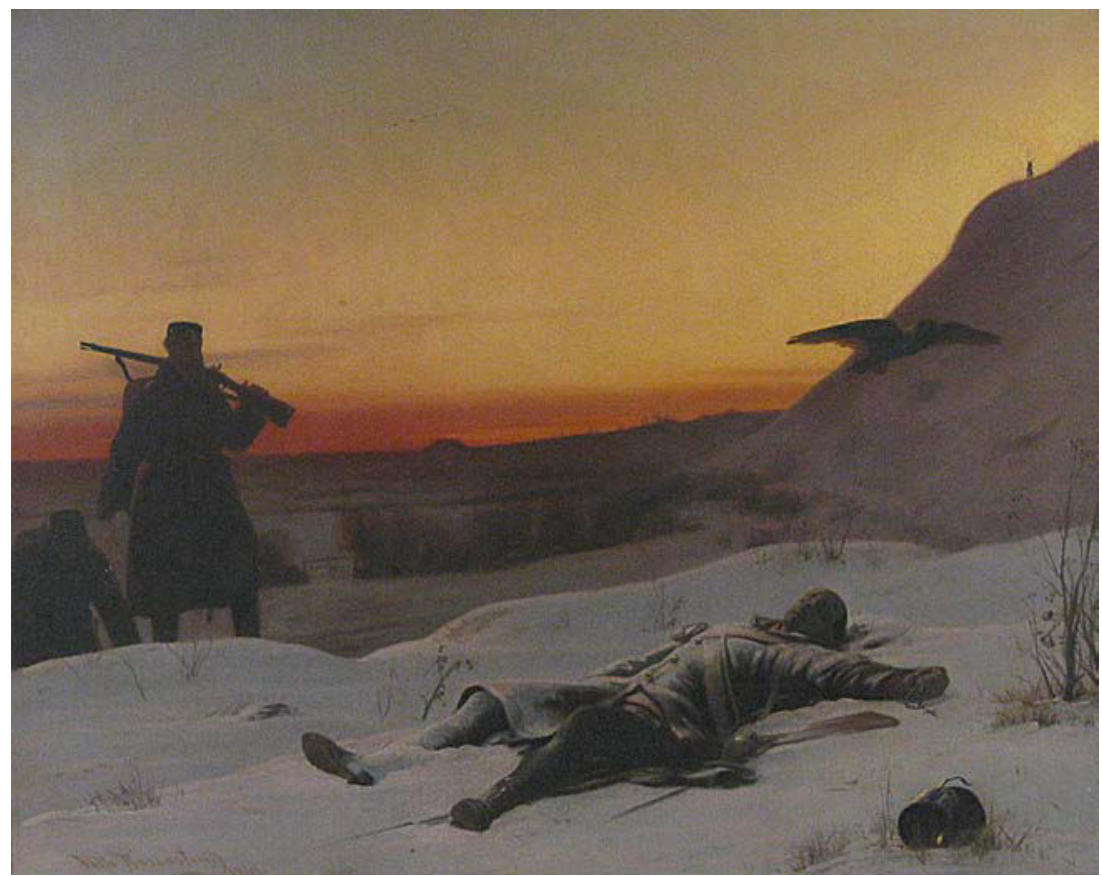

Vilhelm Rosenstand: Fra Saxarmen ved Danevirke Morgenen efter Kampen ved Bustrup 3. februar 1864. Olie på lærred. $66 \times 82 \mathrm{~cm}$. Museum Sønderjylland - Sønderborg Slot. Foto: Søren Petersen.

Maleren Vilhelm Rosenstand var aktiv krigsdeltager. Ved mobiliseringen i 1863 blev han indkaldt som sekondløjtnant ved 20. Regiment, der hørte til 8. Brigade. Han deltog i kampene foran Danevirke og senere ved Fredericia, men ikke ved Dybbøl, da han sammen med andre fra sit regiment var blevet overført til kystbevogtning på Fyn. Rosenstand er nok den kunstner, der mest ihærdigt har omsat sine skitser fra feltlivet til malerier og illustrationer. Scenen her er en af de ret få med en østrigsk soldat. Billedet blev udstillet på Charlottenborg i 1865 og blev erhvervet af den unge løjtnant Vilhelm Dinesen, der havde deltaget i kampen 3. februar og skildret den i sin bog Fra Ottende Brigade (1889). 


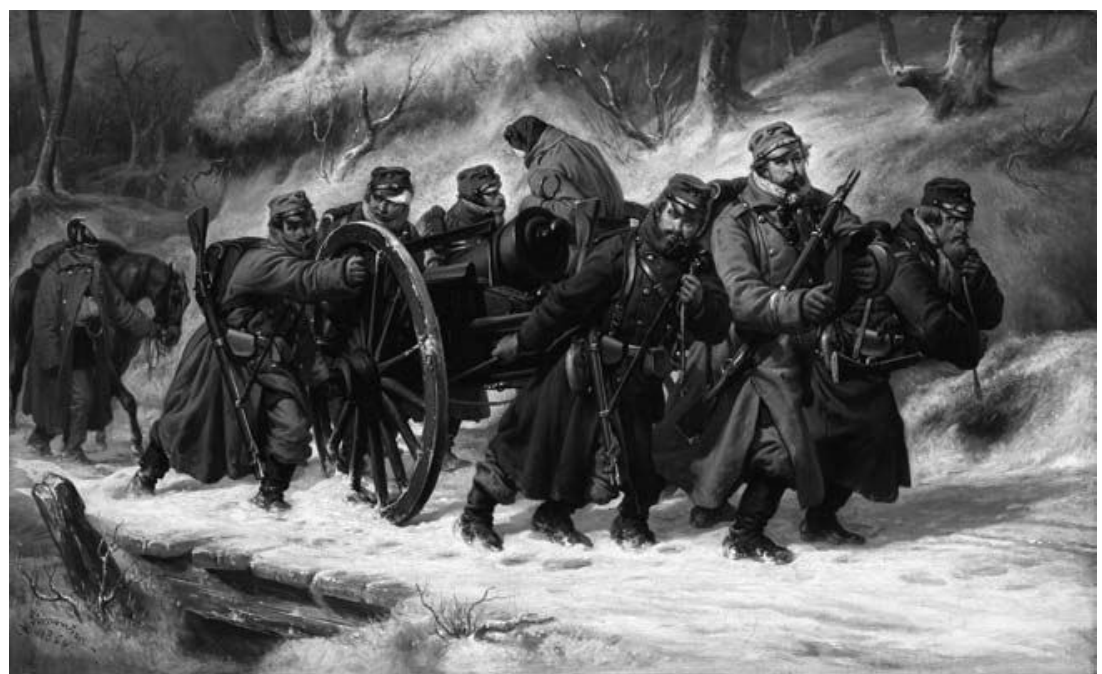

Niels Simonsen: Danske Infanterister trækker en Kanonlavet ved Tilbagetoget fra Dannevirke Stillingen 1864. 1865. Olie på lærred. 48,5 × $80 \mathrm{~cm}$. Det Nationalhistoriske Museum på Frederiksborg Slot. Foto: Lennart Larsen.

Dette billede er selve ikonet på det danske tilbagetog. Det skildrer en konkret episode, hvor nogle danske infanterister valgte at slæbe af sted med en feltkanon, som var blevet efterladt ved vejkanten, efter at et hesteforspand var styrtet. En syg soldat blev sat op på kanonen og undgik herved at blive overladt til kulden og døden. Billedet er malet som en grisaille, dvs. kun i grå farver, men virker alligevel umiddelbart fængende i kraft af sin levende skildring af de ukuelige danske soldater, der trods tilbagetog og truende nederlag havde overskud til at tage vare både på kanoner og kammerater. Maleriet blev udstillet på Charlottenborg i 1865 og blev hurtigt folkeeje og gengivet i talløse reproduktioner. 


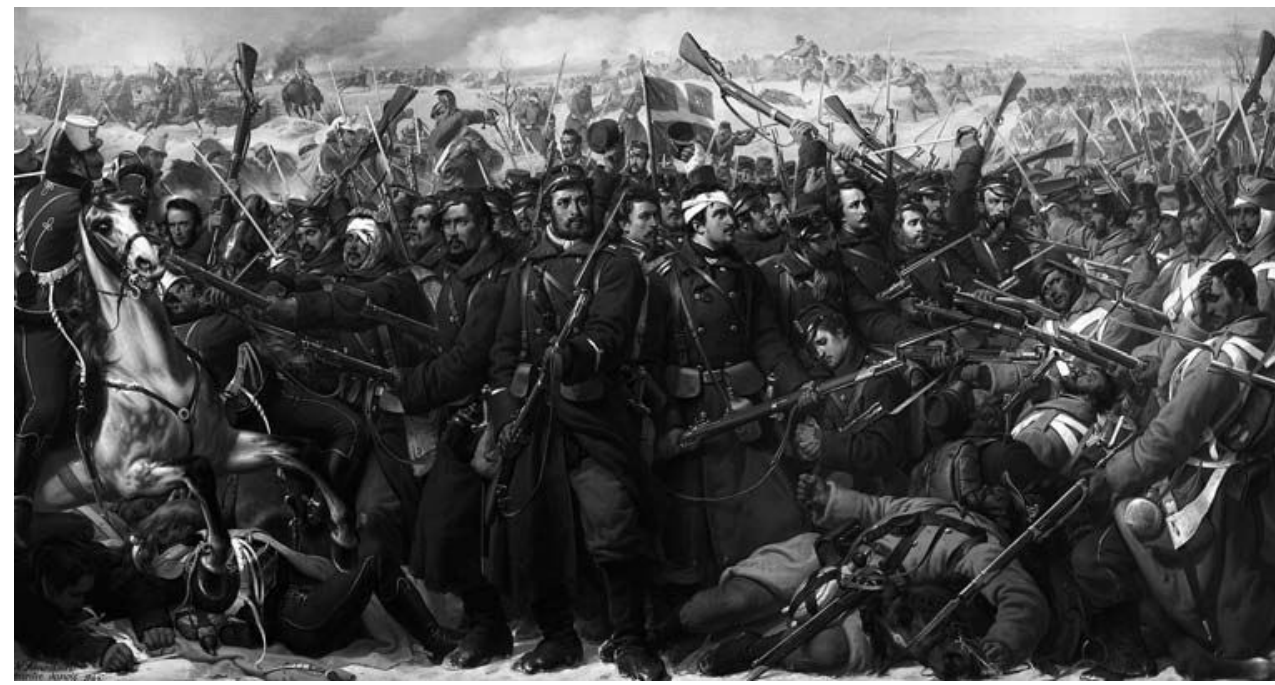

Niels Simonsen: Træfningen ved Sankelmark 6. februar 1864. 1865. Olie på lærred. $163 \times 308$ cm. Jacob A.M.H. Rosenkrantz, Glorup Gods. Foto: Søren Petersen

Under tilbagetrækningen fra Danevirke foregik der en kamp ved Sankelmark over tre timer i isnende kulde mellem danske og østrigske tropper. Det var en nærkamp med brug af bajonetter, der gav betydelige tab på begge sider. Soldaten i midten ligner den ene af de tre soldater, der trækker feltkanonen på Simonsens andet store gråtonemaleri fra tilbagetrækningen. Blandt soldaterne er portrætter af malerens venner, bl.a. den frivillige Jens Paludan-Müller, blomstermaler H. Aumont og oberst Max Müller. Simonsen har udført talrige slagmalerier fra 1848-50, mens dette blev et af hans få fra 1864. Det er præget af nærkampens råhed og blev derfor ikke reproduceret i større omfang. Det var simpelthen for tæt på krigens virkelighed. 


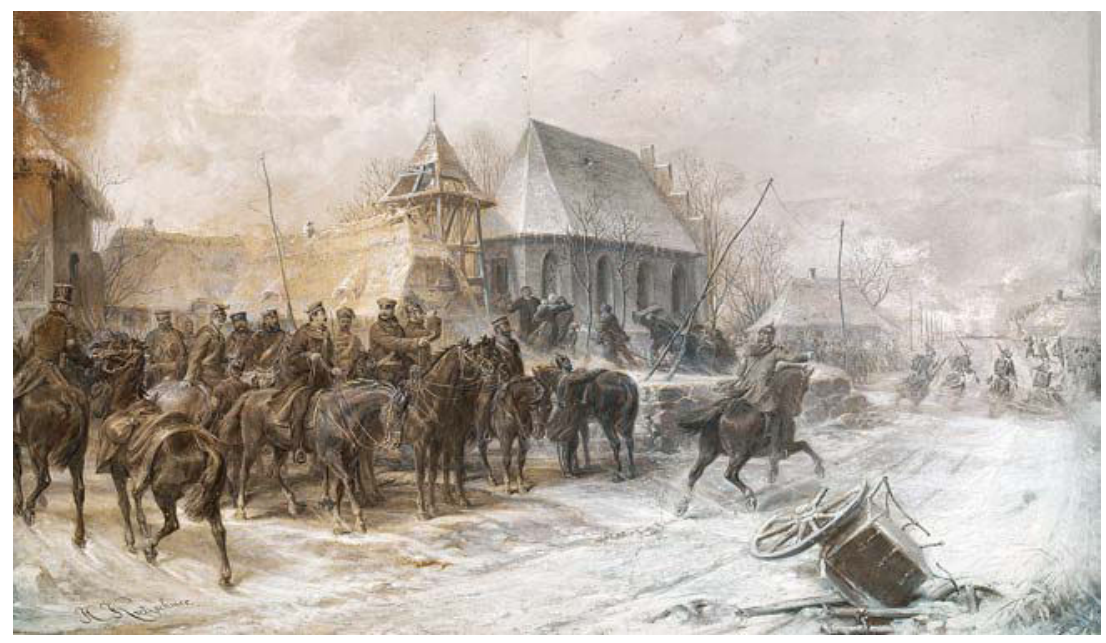

Johann Hermann Kretzschmer: Forpostfxgtning ved Nybøl februar 1864. 1865. Olie på lærred, 50,5 × 74,5 cm. Museum Sønderjylland - Sønderborg Slot. Foto: Søren Petersen.

Berlinerkunstneren J.H. Kretzschmer kom som billedreporter til den tysk-danske slagmark og indgik i den preussiske prins Friedrich Karls stab. Han udførte især malerier med populære motiver som prins Friedrich Karl på Dybbøl og overgangen til Als, men han malede også mindre spektakulære scener, for eksempel med preussiske troppers rekognoscering i Sundeved. Billedet her viser et af de første sammenstød mellem preussiske og danske tropper efter tilbagetrækningen fra Danevirke. I forgrunden ses preussiske tropper, i baggrunden anes danske tropper. Midt i billedet ses lokale beboere, der under kampen søger tilflugt i kirken. Civile på flugt fra krigens gru skildres kun sjældent i historiemaleriet. 


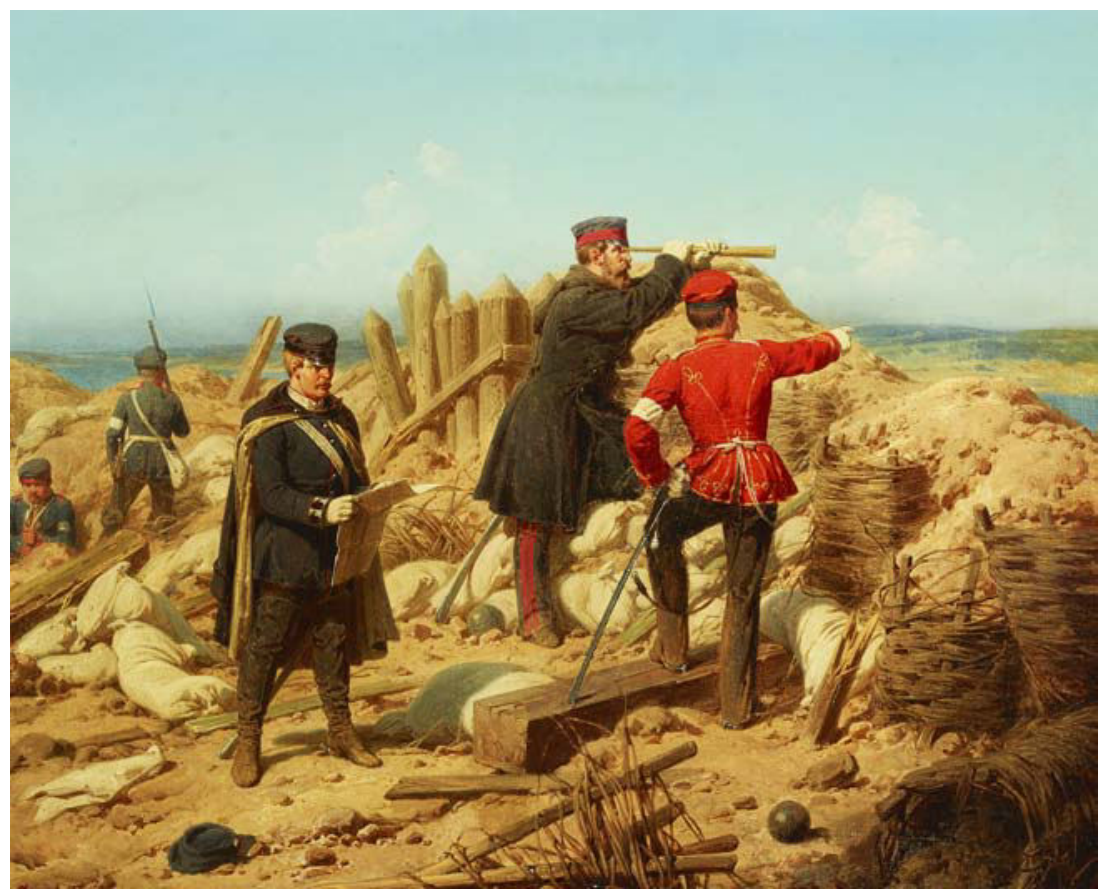

Christian Sell: Den preussiske kronprins og prins Friedrich Karl på slagmarken ved Dybbøl. 1864. Olie på lærred, $48 \times 60 \mathrm{~cm}$. Museumsberg Flensburg. Foto: Smstds.

Christian Sell deltog som maler for den preussiske hær i de tre såkaldte tyske foreningskrige 1864, 1866 og 1870-71. På dette maleri gengiver han de sejrende i feltherrepositur efter erobringen af Dybbøl Skanser. Den øverstbefalende for det preussiske armekorps, prins Friedrich Karl med rød uniformsjakke, står rygvendt og forklarer den preussiske kronprins Friedrich om krigsskuepladsen. Kronprinsen retter sin kikkert mod de fjendtlige stillinger på Als. Bag dem står en preussisk officer, der nøje studerer en situationsplan. Det giver alt sammen indtryk af planlægning, strategi og overblik. Den preussiske kronprins var på besøg på Dybbøl 21. april efter at have overværet en sejrsparade i Adsbøl. 


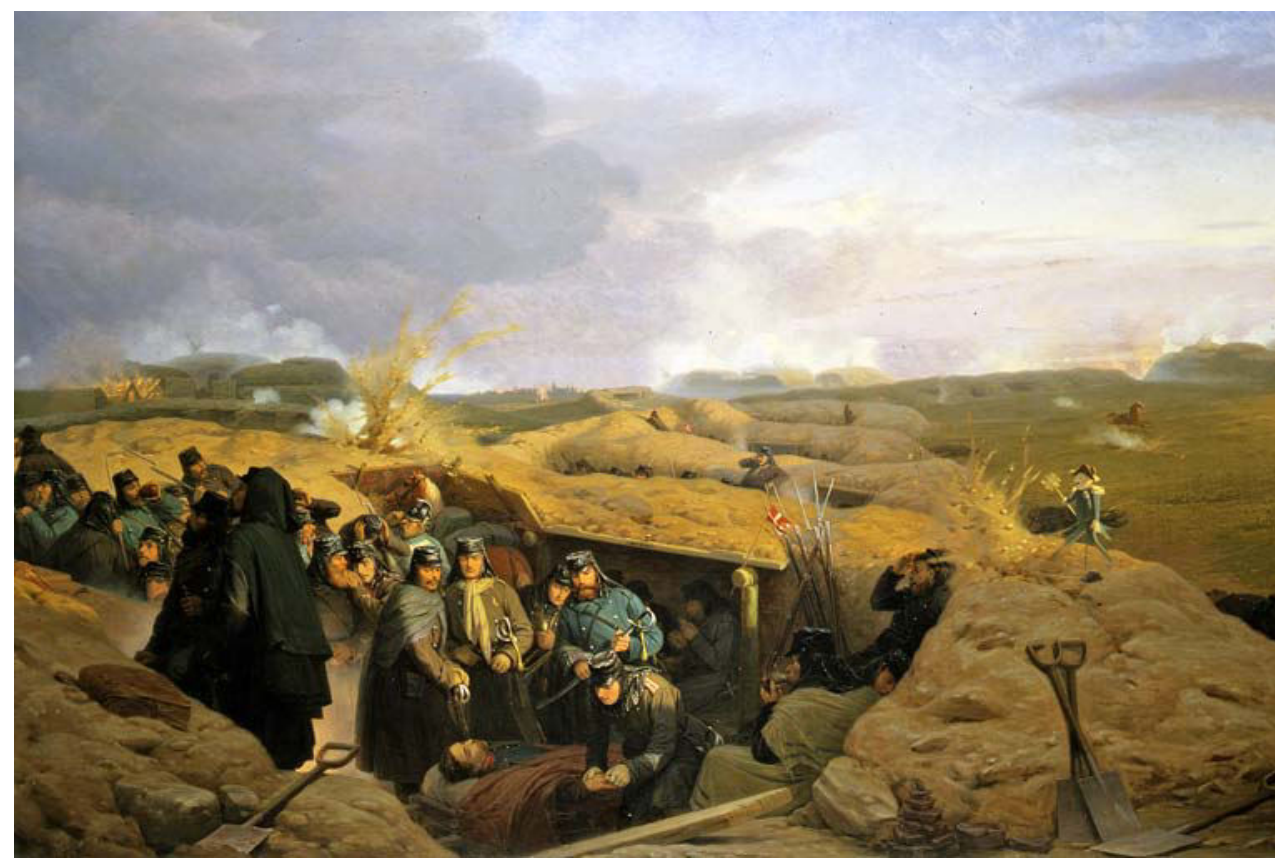

Jørgen V. Sonne: Fra Dybbøl først i april 1864. 1871. Olie på lærred. $130 \times 194 \mathrm{~cm}$. Det Nationalhistoriske Museum på Frederiksborg Slot. Foto: Lennart Larsen.

Billedet viser de delvist sønderskudte skanser med en falden officer i forgrunden og konstante granatnedslag i baggrunden. Det afspejler en fortvivlende situation og et udsigtsløst forsvar. Sonne havde oplevet situationen, da han med tilladelse fra Krigsministeriet færdedes ved slagmarken med sin skitsebog. Hans skitser og oliemalerier har præg af troværdig krigsreportage, sædvanligvis dog uden gru og med hovedvægt på skildringen af de danske soldaternes mod og udholdenhed. Sonne har også udført talrige billeder fra 1848-1850, mens der fra krigen 1864 kun kendes tre værker. Det har været tungt for ham at få afsluttet skildringen af den håbløse situation på Dybbøl, og billedet blev først færdig i 1871. 


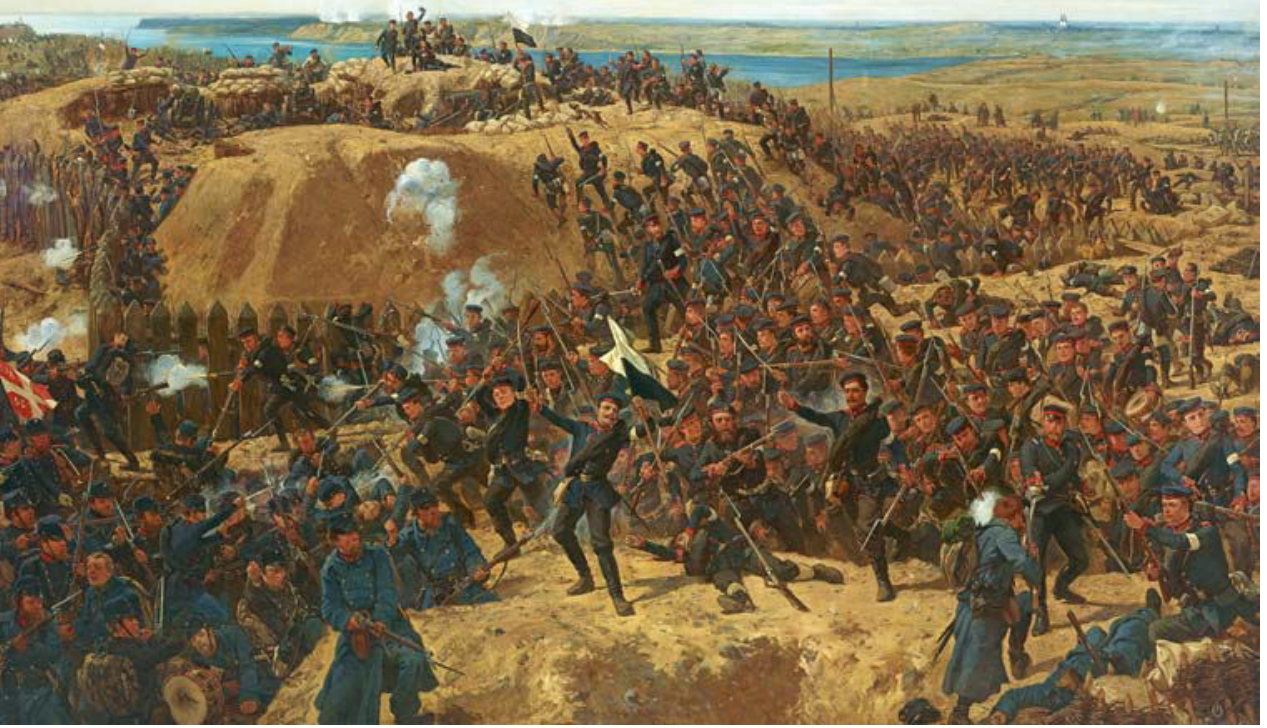

Fritz Schulz: Stormen på Dybbøl Skanse V. 1865. Olie på lærred, $188 \times 253 \mathrm{~cm}$. Schleswig-Holsteinische Landesbibliothek. Foto: Smstds.

Den berlinske militærmaler Fritz Schulz skabte med dette storslåede panoramabillede en detaljerig skildring af et slag og samtidig også et omfattende gruppeportræt. Billedet er udført på bestilling af prins Friedrich Karl, der er gengivet i sin røde uniformsjakke på bakken i baggrunden til højre, hvorfra han iagttager stormen på Dybbøl Skanser. I fokus for kompositionen står en af de tyske Dybbøl-helte, Feldwebel Probst, der er skildret som triumfator i det øjeblik, hvor han kan sætte den preussiske stormfane i jorden på Skanse V. Umiddelbart herefter blev han ramt af en dansk kugle og døde. Hans indsats blev kendt i samtiden og blev hyldet $i$ et populært digt af Theodor Fontane: »Der Tag vor Düppel«. 


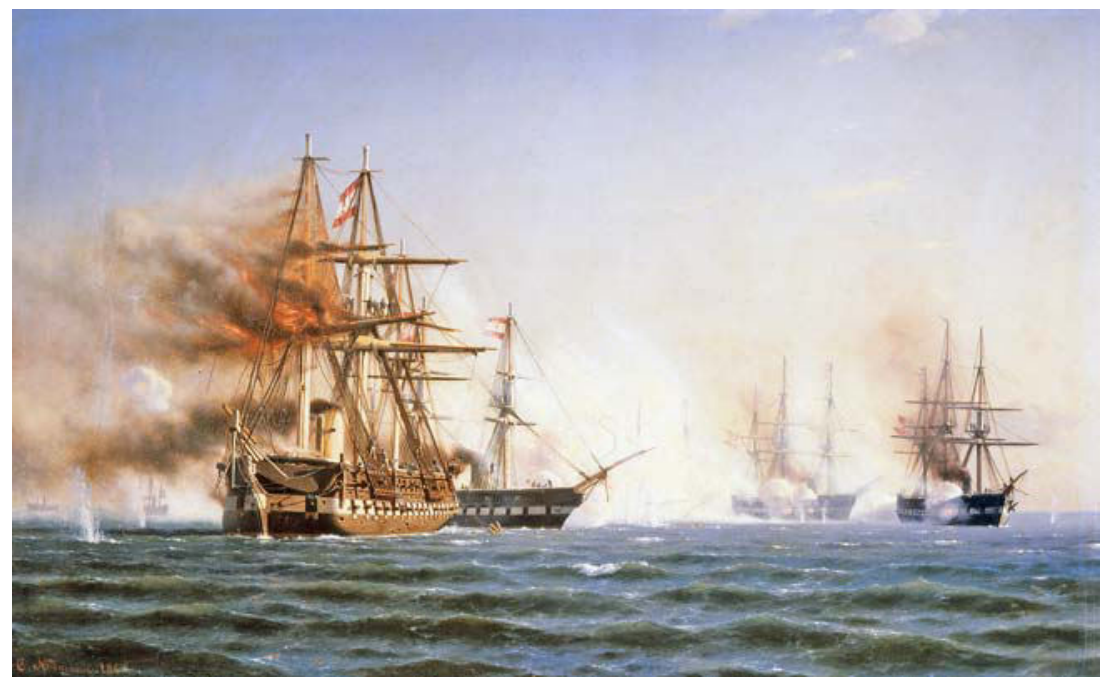

Carl Neumann: Slaget ved Helgoland. 1865. Olie på lærred. $64 \times 103 \mathrm{~cm}$. Fyns Stiftsmuseum, deponeret i Museum Sønderjylland - Sønderborg Slot. Foto: Sønderborg Slot.

Søslaget foregik 9. maj mellem to østrigske fregatter og tre preussiske kanonbåde over for to danske fregatter og en korvet. Maleren har skildret det øjeblik, hvor den østrigske fregat »Schwarzenberg« er skudt i brand, og den anden østrigske fregat glider frem for at dække den mod beskydning fra de to danske fregatter "Jylland « og »Niels Juel«. Kampen ophørte først, da den østrigsk-preussiske eskadre trak ind på neutralt farvand ved Helgoland. Det var den eneste større kamp i krigen 1864, der med rimelighed kunne tolkes som en dansk sejr. Derfor er den skildret både af samtidige og senere malere. Neumanns detaljerige billede bygger på en skitse af en søløjtnant, der var om bord på den danske korvet. 


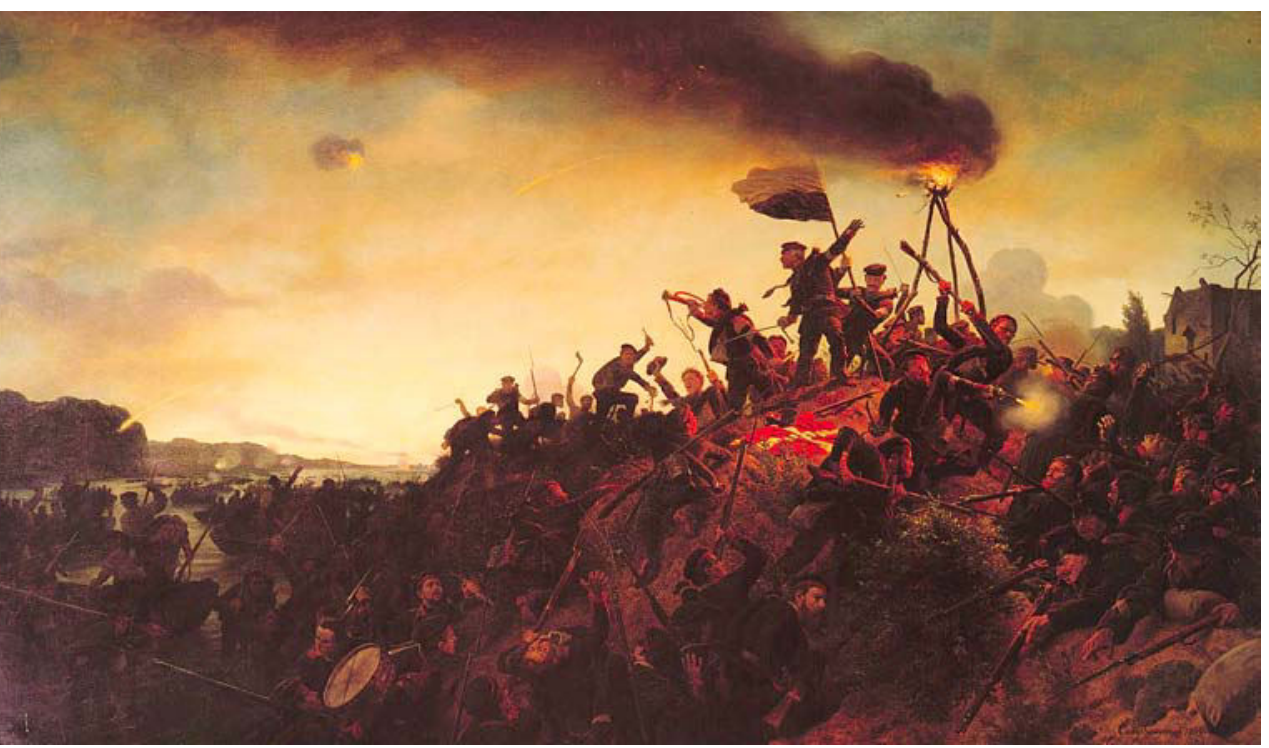

Wilhelm Camphausen: Overgangen til Als. 1866. Olie på lærred, $165 \times 284 \mathrm{~cm}$. Deutsches Historisches Museum, Berlin. Foto: Sønderborg Slot.

Camphausen var en fremtrædende tysk historiemaler allerede før 1864. Han rejste i april 1864 til Sundeved for at opleve krigens realiteter og udførte talrige skitser og skrev dagbog om sine oplevelser. Skitserne blev omsat til store oliemalerier, der blev udført på bestilling af den preussiske kongefamilie. De fleste er dog gået tabt i Anden Verdenskrig, men skildringen af den dristige overgang til Als 29. juni er bevaret. Motivet glorificerer triumfen, men giver dog et realistisk billede af, hvorledes de danske tropper blev løbet over ende. Camphausen udgav senere en illustreret dagbog med sine oplevelser i 1864, hvor han uforblommet skildrer krigens grusomheder, landskabets ødelæggelse og de såredes lidelser. 


\section{De senere skildringer af krigen}

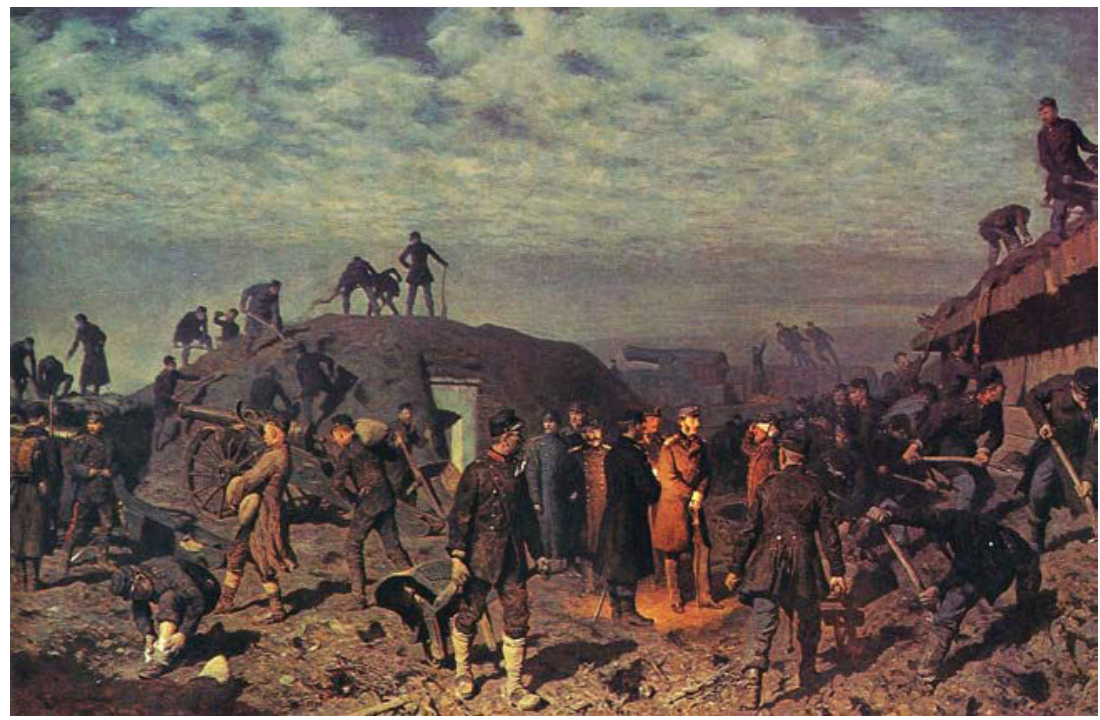

Otto Bache: Christian den Niendes Besøg i Dybbøl Skanser. 1888. Olie på lærred. $164 \times 250 \mathrm{~cm}$. Tilhører Hendes Majestæt Dronningen, deponeret på Sønderborg Slot siden 1976. Foto: Søren Petersen.

Den 22.-23. marts var Christian IX på besøg ved fronten og besøgte om natten mandskabet i Skanse II. Denne episode er fastholdt af Otto Bache i dette store, figurrige billede, der blev skænket til Christian IX ved hans 25-års regeringsjubilæum i november 1888 af officerer, underofficerer og befalingsmænd. Der er lagt vægt på at portrættere ledende officerer, bl.a. general Gerlach og oberst H.A.T. Kaufmann. Christian IX er dog ikke afbildet i samtale med disse, men med en såret menig, og det antydes hermed, at kongen nærer omsorg for hele sin hær og ikke kun for officererne. Andre menige er ved at udbedre skaderne efter dagens bombardementer, i baggrunden tv. ses krudtmagasinet og th. blokhuset til mandskabet. 


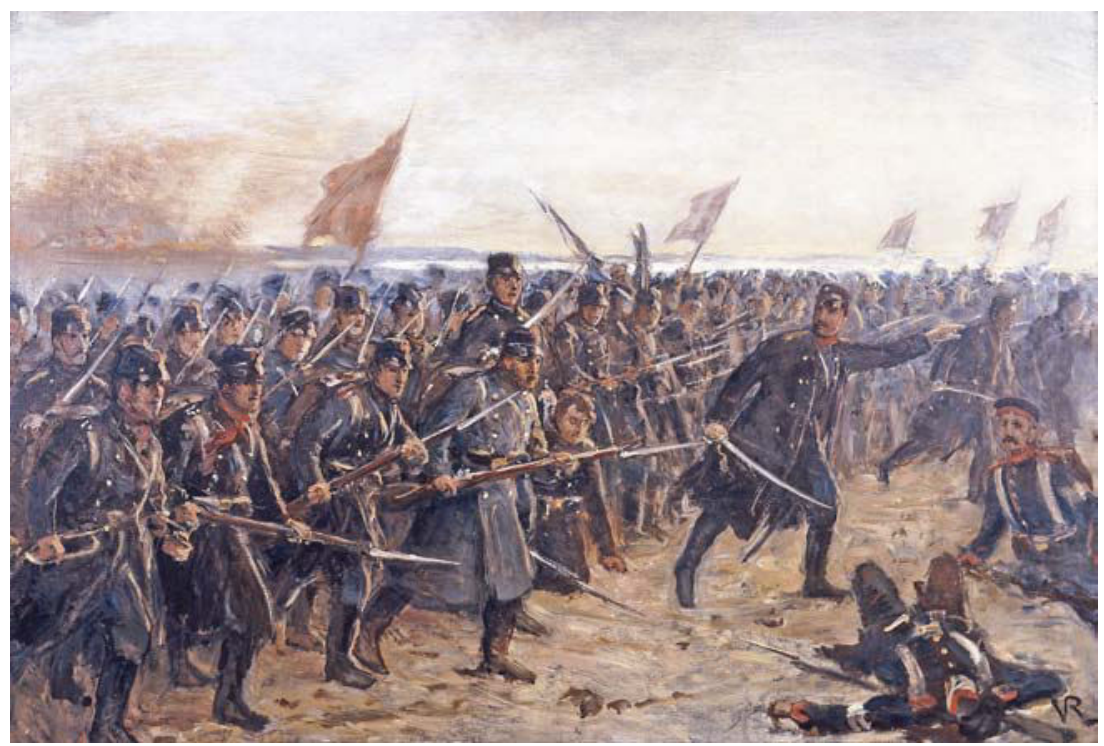

Vilhelm Rosenstand: Episode af Ottende Brigades Modstød. 1894. Olie på lærred. 71 $\times 102 \mathrm{~cm}$. Skitse til stort maleri i Det Nationalhistoriske Museum på Frederiksborg Slot. Deponeret på Sønderborg Slot af Kunstmuseet Fuglsang. Foto: Søren Petersen.

Ottende Brigades ihærdige, men forgæves forsøg på at trænge de preussiske stormtropper tilbage den 18. april blev skildret litterært $\mathrm{i}$ 1889 af Vilhelm Dinesen, der som ung løjtnant deltog i denne kamp. Hans bog, Fra Ottende Brigade, der er skrevet i heroiserende stil, inspirerede Vilhelm Rosenstand til et stort slagmaleri, der i dag er på Det Nationalhistoriske Museum på Frederiksborg. Skitsen, der ses her, har ikke samme grad af patos som det endelige billede. Men fælles for dem er skildringen af soldaternes kampvilje på trods af udsigten til nederlag. Mandskabet i skanserne havde fra 7. februar ligget i dækning i stillingen, hvorfra der kun foretaget en enkelt offensiv 17. marts, der tilmed endte fatalt. 


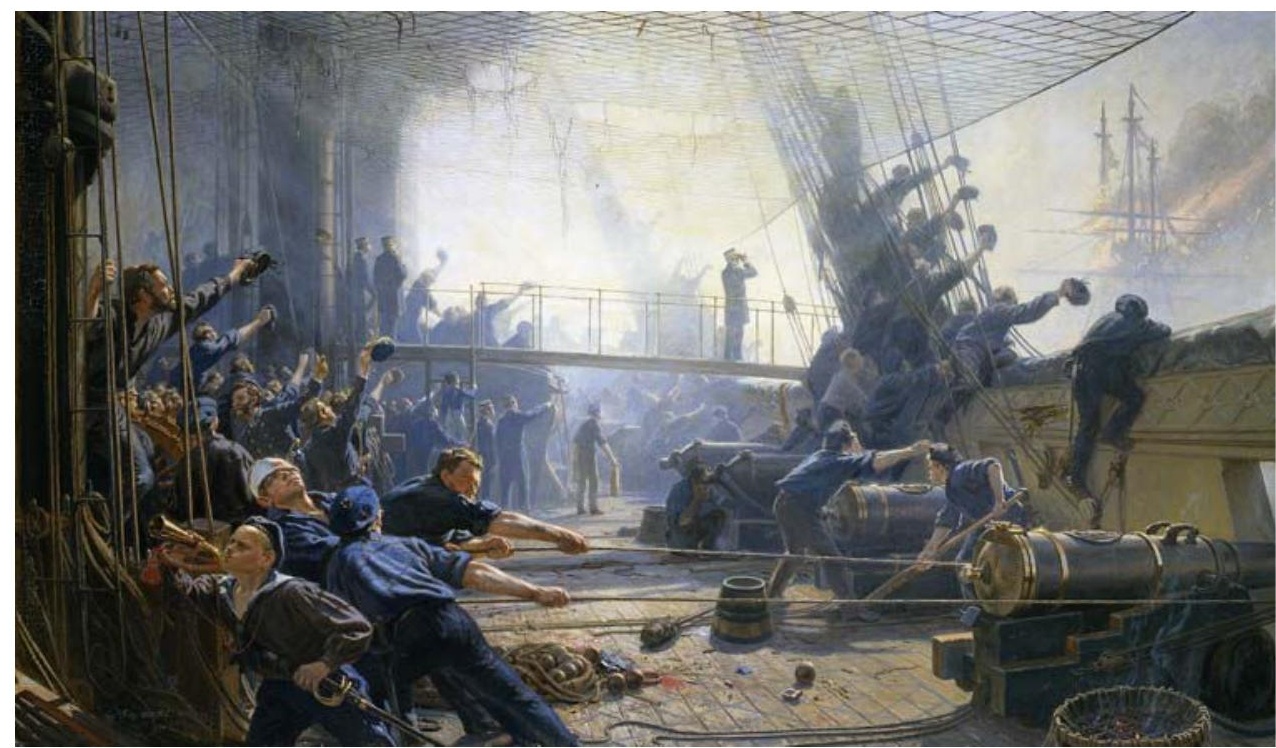

Christian Ferdinand Andreas Mølsted: Om bord på fregatten Niels Juel under slaget ved Helgoland. 1898. Olie på lærred. $110 \times 185 \mathrm{~cm}$. Det Nationalhistoriske Museum på Frederiksborg Slot. Foto: Kit Weiss.

Motivet er batteridækket på fregatten Niels Juel, hvor mandskabet begejstres ved at se resultatet af deres ihærdige indsats - den østrigske fregat Schwarzenberg er skudt i brand. Mens mandskabet ved kanonerne jubler, står orlogskaptajn Suenson helt rolig på kommandobroen og følger kampen nøje. Det er nationalromantisk skildring af arbejdet på batteridækket, hvor der var tæt krudtrøg og infernalsk larm både fra batteriets egne kanoner og kanonerne på dækket ovenover blandet med buldren fra østrigernes kanoner. Mandskabet arbejdede med bar overkrop på grund af det hårde slid og den kvælende varme fra kanoner. Chr. Mølsted var habil marinemaler, men skildrede ikke krigens barske realiteter. 


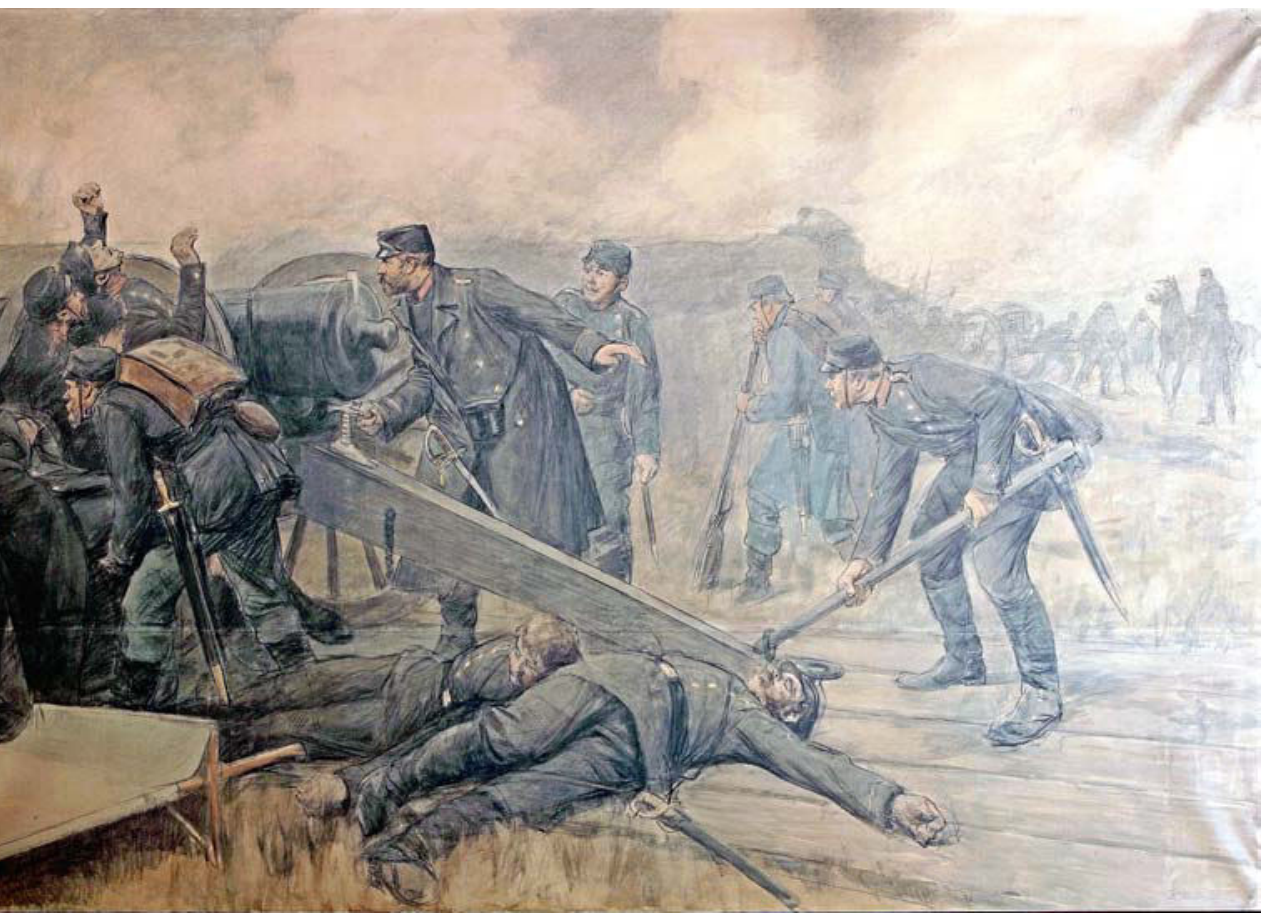

Erik Henningsen: Kampen ved Mysunde 2. februar. 1914. Kultegning på pap. $110 \times$ $330 \mathrm{~cm}$. Fanegemakket på Christiansborg Slot. Foto: Smstds.

Ved genopførelsen af det nedbrændte Christiansborg Slot 1906-1928 blev kongefløjen udsmykket med kunst, der afspejlede både kongehusets og folkets historie. Det var værker af den type, som brygger J.C. Jacobsen havde betegnet som »vækkende Fremstillinger af det danske Folks historiske Minder «. ${ }^{2}$ Audiensgemakket var førhen blandt de rum, som flest borgere havde mulighed for at opleve, og forrummet hertil, fanegemakket, blev i 1914 udsmykket med fire store billeder udført af Erik Henningsen. ${ }^{3}$ De skildrede spektakulære begivenheder fra den tabte krig, der også har været yndede motiver for historiemalere. 


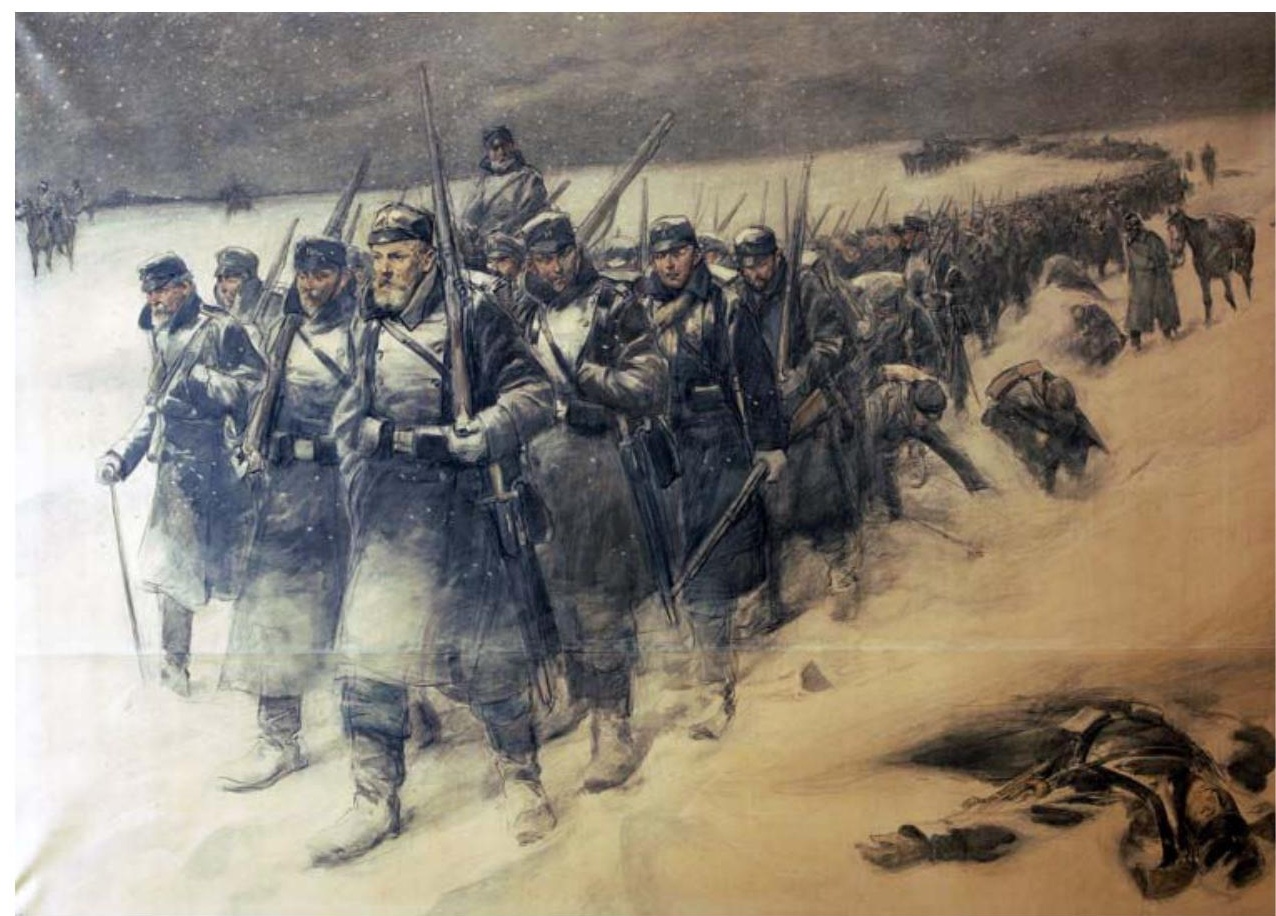

Erik Henningsen: Tilbagetoget fra Danevirke. 1914. Kultegning på pap. $110 \times 330$ cm. Fanegemakket på Christiansborg Slot. Foto: Smstds.

I modsætning til de danske historiemalerier, der blev udført i slutningen af 1800-tallet, er Erik Henningsens billeder fra 1864-krigen er uden patos og mere realistiske i stilen. Især hans skildring af tilbagetogets isnende kulde med døde soldater efterladt i sneen langs vejen er medrivende. Det er de menige soldater som anonyme helte, som dette billede viser. Vilhelm Dinesen, der deltog i tilbagetoget, har skildret det således: »Når vi kom op på en bakketop og så forud, bølgede, så langt øjet rækkede, en sort stribe langs landevejen som et uhyre ligtog, langsomt, dødstille; det var den danske hær, der erkendte fjendens overmagt.« 

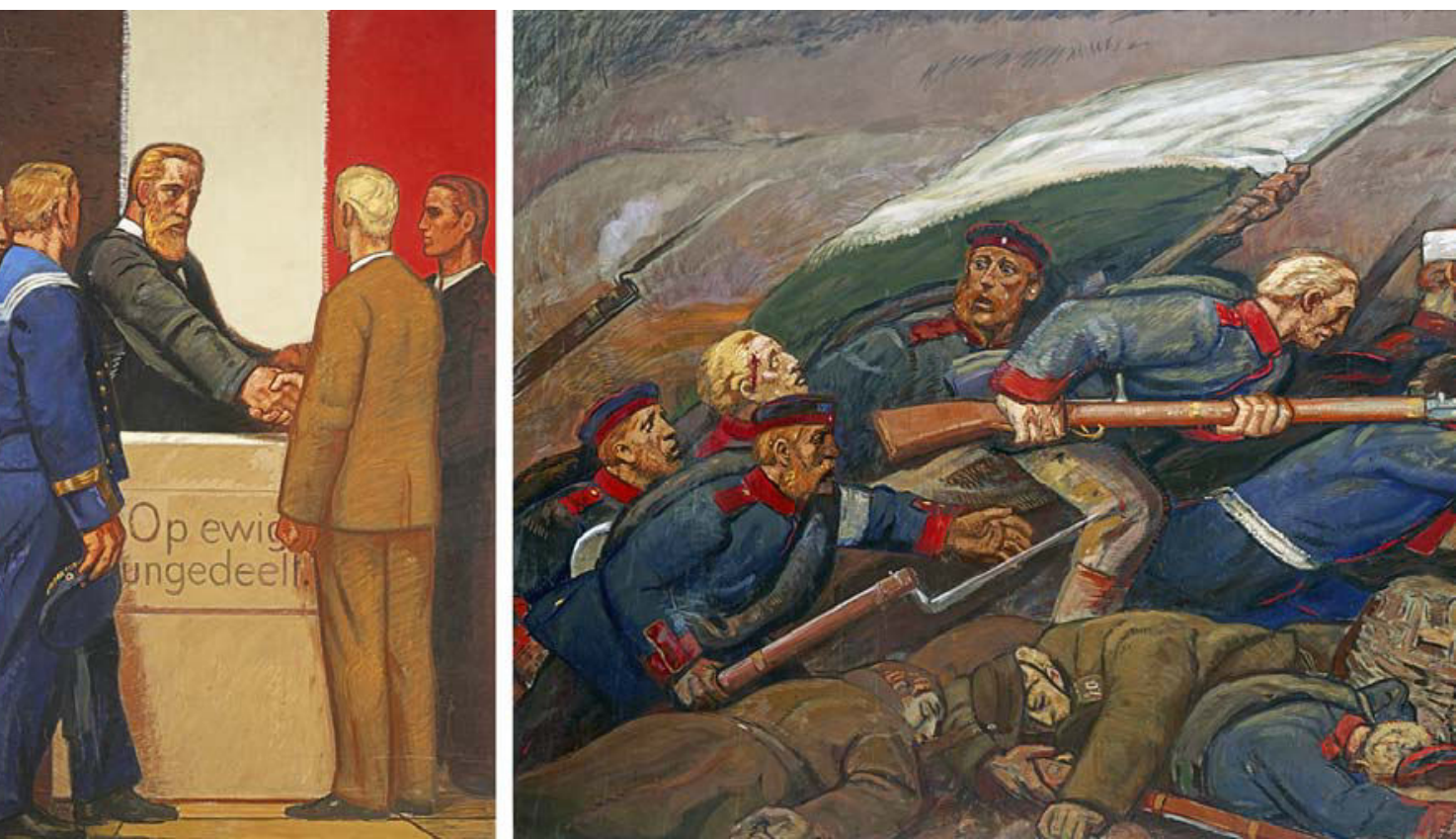

Ludwig Dettmann: Stormen på Dybbøl. 1914. Olie på lærred. Triptykon, midterste del måler $256 \times 576 \mathrm{~cm}$, sidefløjene $282 \times 199 \mathrm{~cm}$. Schleswig-Holsteinische Landesbibliothek. Foto: Smstds.

I det nu nedrevne ridehus foran Sønderborg Slot blev der i 1914 vist en stor mindeudstilling i anledning af 50-årsdagen for slaget på Dybbøl og erobringen af Als. Her deltog den slesvig-holstenske kunstner Ludwig Dettmann med en triptykon, dvs. et maleri. I midterfeltet skildres stormen på Dybbøl Skanser, mens motiverne på sidefløjene perspektiverer kampen ved at skildre dens forudsætninger og følger. Det monumentale tredelte maleri, der måler ca. 10 meter i bredden, var mindeudstillingens dramatiske finale i det sidste rum, den såkaldte »Ehrenhalle«. Ikke mindst skildringen af fremadstormende preussiske soldater i heftig nærkamp med skræmte danske soldater under en overdimensioneret stormfane, vakte samtidens beundring. 

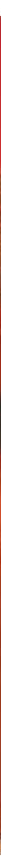

På sidefløjene refererer Ludwig Dettmann til krigens forhistorie og følger og sammenknytter slesvig-holstensk og preussisk historie til en tysk patriotisk fortælling. Til venstre står en gruppe unge foran kejserrigets sort-hvid-røde fane og sværger troskab. De udveksler et bekræftende håndtryk hen over et mindesmærke, hvori der er indhugget »Op ewig ungedeelt«, den slesvig-holstenske parole fra 1840'ernes nationale kamp. Til højre bliver ofrene i 1864-krigen mindet og hyldet med en laurbærkrans. Det foregår ved en af de endnu eksisterende mindesten på massegravene på Dybbøl Banke. Indskriften er delvist dækket, og beskueren må selv gætte, om der står 207 tapfere Dänen eller Preussen. 


\section{Samtidshistoriske kommentarer}

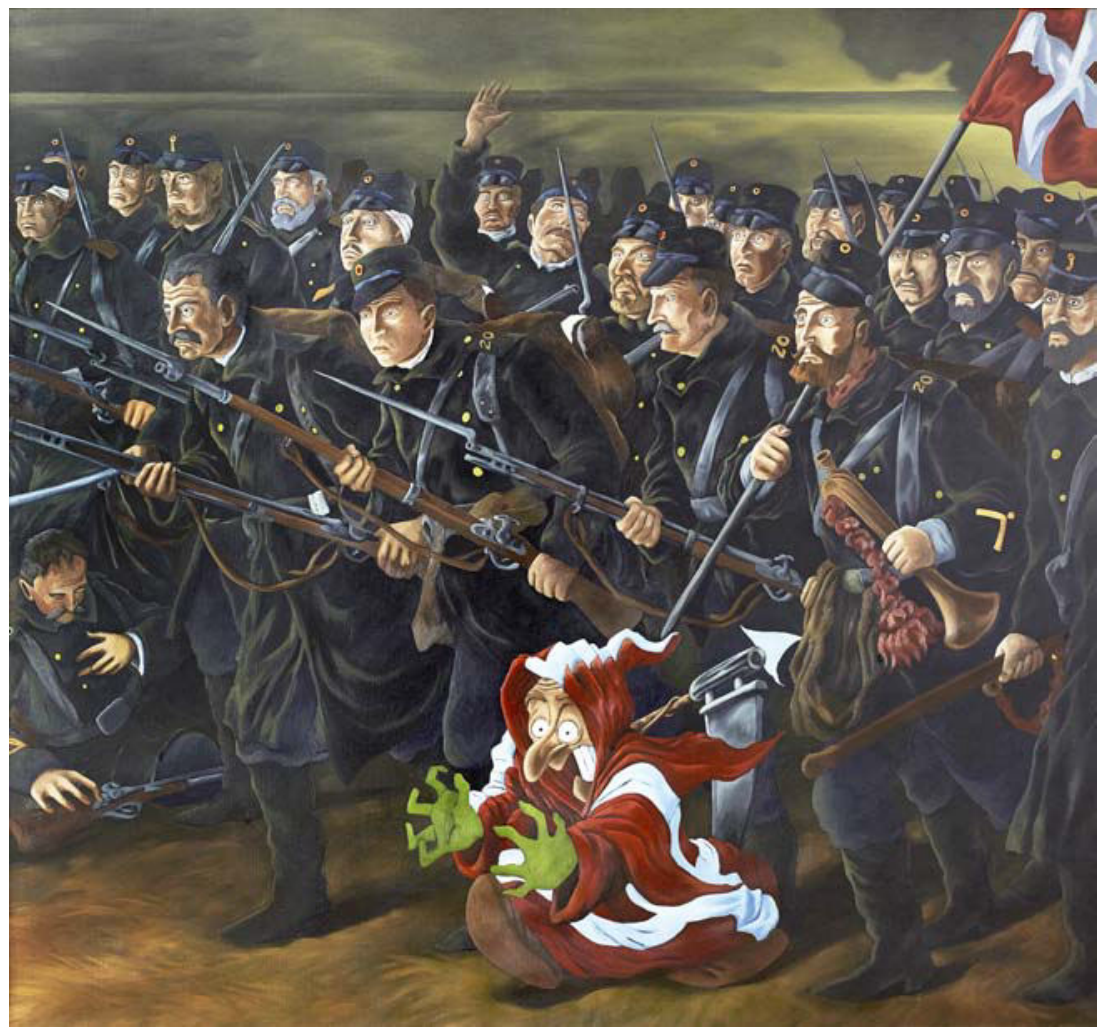

Martin Bigum: National Retreat (Millennium). 1996. Olie på lærred. $200 \times 210 \mathrm{~cm}$. Kunstmuseet ARKEN, deponeret på Sønderborg Slot. Foto: Søren Petersen.

Nogle billeder fra 1864-krigen er indgået i historiebevidstheden, og derfor kan nutidige malere genbruge motiverne. Dette billede tager afsæt i Vilh. Rosenstands skildring af Ottende Brigades Angreb (s. 42). Bigum gengiver danske soldater på Balkan i 1990'erne iført 1864uniformer. Blandt officererne ses Uffe Ellemann Jensen, udenrigsminister 1982-1993 og fortaler for en aktiv dansk udenrigspolitik. Forrest ses en lille figur »Art«, der kendes fra andre af Bigums billeder. Hans rædselsslagne ansigt og leen, der hviler på hans skulder og ikke er i brug, står i skarp kontrast til soldaterne, der er i færd med at gå løs på fjenden med bajonetter. Det er en skarp kommentar til udsagn om, at Danmark var kommet ud af skyggen af 1864. 


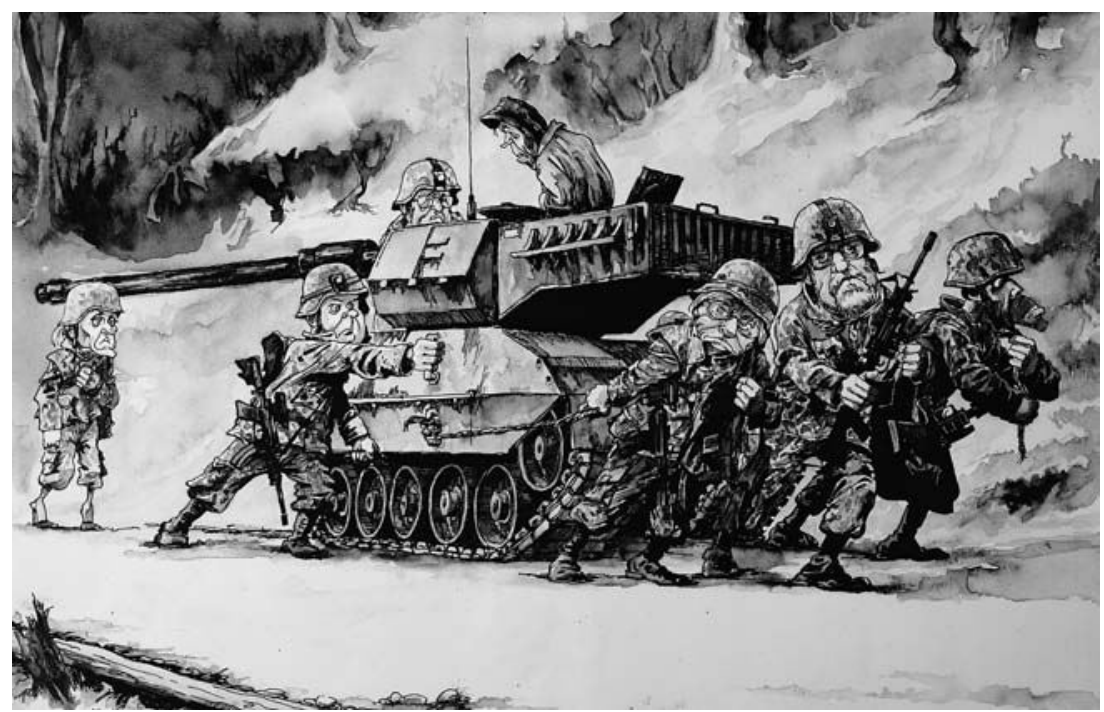

Roald Als: Tilbagetrækning af danske styrker fra Afghanistan. Bladtegning til Politiken 21. juli 2013. Signeret computerprint. $30 \times 42 \mathrm{~cm}$. Museum Sønderjylland Sønderborg Slot. Foto: Smstds.

Tegningen illustrerede en analyse af chefredaktør Bo Lidegaard om de danske troppers indsats i Afghanistan. Han konkluderede, at trods betydelige tab havde resultatet af indsatsen været tæt på nul. ${ }^{4}$ Roald Als har lavet en parafrase over Niels Simonsens tilbagetog fra Danevirke (s. 32). Her trækkes kanonen af borgerlige politikere, der var ved magten, da danske tropper blev sendt til Afghanistan. Fra højre ses Anders Fogh Rasmussen, Per Stig Møller, Pia Kjærsgaard og Søren Gade. Siddende på kanonen og bag den ses tidligere oppositionspolitikere, der som regering videreførte den aktivistiske udenrigspolitik. Fra venstre ses Helle Thorning Schmidt, Niels Helveg Petersen og den rygvendte Villy Søvndal. 


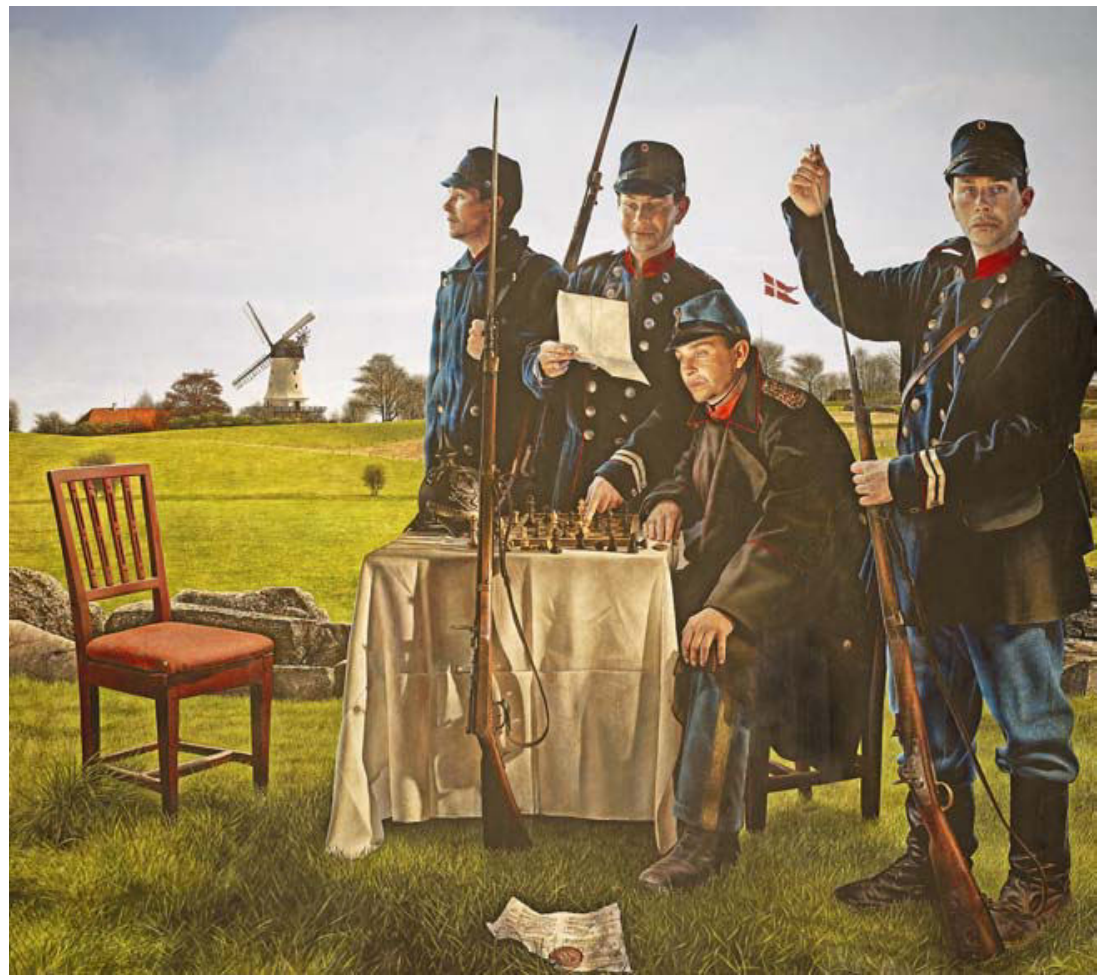

Thomas Kluge: Dybbøl 1864. 2014. Olie på lærred. $200 \times 210$ cm. Museum Sønderjylland - Sønderborg Slot. Foto: Søren Petersen

Billedet viser en scene fra krigen 1864 i det nutidige kulturlandskab i Dybbøl Skanser. Ved et bord ses tre danske menige og en officer. En tom stol og en efterladt pikkelhjelm viser, at en preussisk officer har forladt scenen. På bordet er et skakbræt med et uafsluttet spil, 'hvid' vil dog blive skakmat i næste træk. I græsset ligger en skillingsvise, »Jens var aldrig bange, men de var for mange«, sammen med en medalje med indskriften: »For hvert et tab igen erstatning findes; hvad udad tabtes, det må indad vindes«. Inden for rammerne af en magisk, symbolsk realisme inddrager billedet kendte nationalhistoriske elementer, men fortællingen er uheroisk og rejser spørgsmålet om, hvem der var sejrherre. 


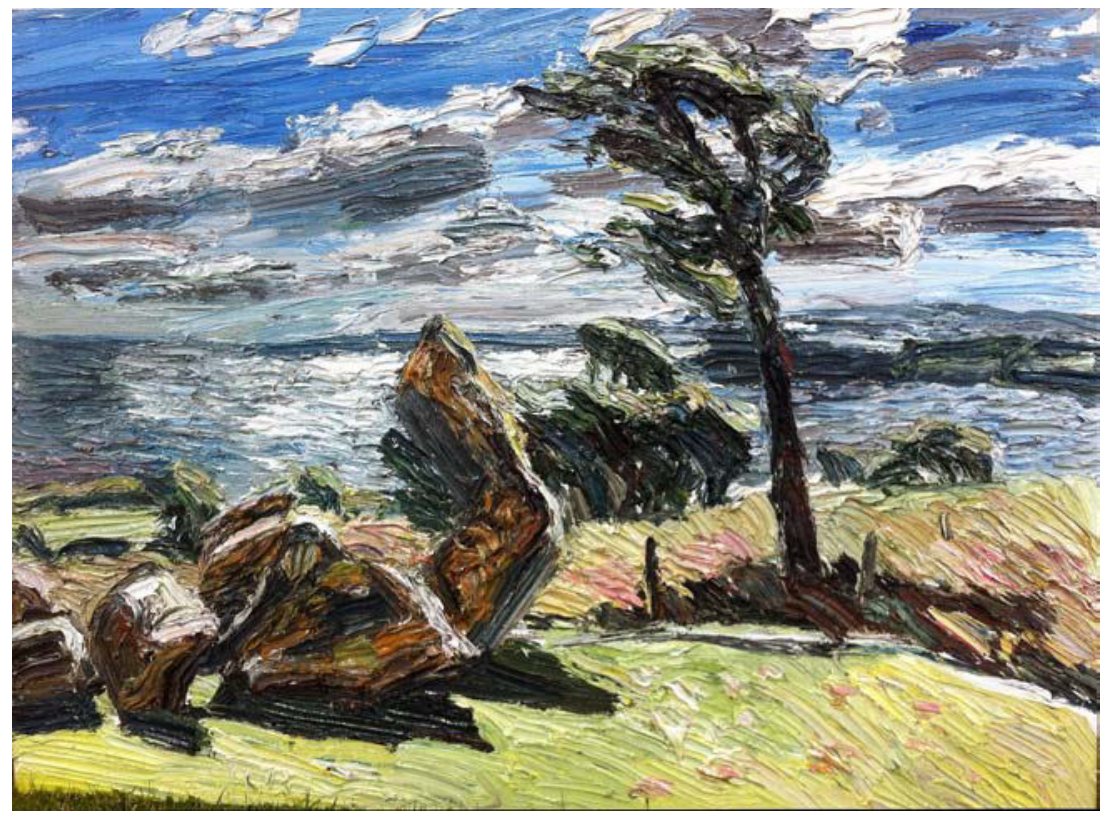

Christopher Lehmpfuhl: Düppeler Schanzen. 2013. Olie på lærred. $180 \times 240 \mathrm{~cm}$. Itzehoer Versicherung. Foto: Florian Selig.

Christopher Lehmpfuhl fra Berlin er næsten jævnaldrende med Thomas Kluge, men har i modsætning til Kluge valgt ikke at skildre krigen, men dens virkning set i perspektiv af 150 år. Det er mere et impressionistisk landskabsmaleri end et egentlig historiemaleri med fortællende indhold. Scenen er det nutidige kulturlandskab i skanse 4 med ruiner af danske krudtmagasiner og en vid udsigt ud over Flensborg Fjord mod den tyske kyst. Grænselandets oprørte historie udtrykkes i det centimetertykke farvelag, der giver en reliefagtig karakter. Billedet får en oprørt karakter, som om slaget om Dybbøl snart vil gå i gang igen. Men striden er endt med et forsonende resultat, for horisonten er udvidet og grænserne flydende. 


\section{Sammenfatning}

En sammenligning mellem danske og tyske historiemalerier viser betydelige forskelle i motivvalget, og de skyldes ikke kun, at der i store og små nationer udvikles forskellige mentaliteter og samhørigheder. Hvis man sammenligner danske historiemalerier fra 1848-50 og 1864, så er der også markante forskelle i motivvalget, og det gælder for eksempel for en maler som Jørgen Sonne, der har udført billeder fra begge krige. Fra Første Slesvigske Krig er de foretrukne motiver billeder fra slag og træfninger, der kunne tolkes som sejre. Det var derimod sværere at finde sejrrige danske træfninger og slag fra Anden Slesvigske Krig, og malerne har derfor i vidt omfang fravalgt slagscener til fordel for skildringer af de danske soldaters udholdenhed og mod. Motiverne begrænser sig til ret få lokaliteter og kamphandlinger, først og fremmest kampen ved Mysunde 2. februar før tilbagetrækningen fra Danevirke, træfningen ved Sankelmark 6. februar, kampene på Dybbøl samt et par rytterfægtninger. Skildringerne fra krigen til søs er indskrænket til de kampe, der kan betegnes som sejre - eller i det mindste som vellykkede udfald. Det drejer sig om træfningerne ved Rügen og Helgoland. Derimod er ingen danske historiemalere gået i kast med at skildre overgangen over Alssund og kampen om Als 29. juni eller den sidste og helt overflødige træfning, der foregik 3. juli ved Lundby i Himmerland. Krigens to sidste kampe medførte betydelige tab, og det var umuligt at fremstille dem i heroisk lys, og de er kun skildret i bogillustrationer, der er udført årtier efter begivenhederne.

De tyske historiemalerier har i et vist omfang andre motiver, da malerne også her helst vælger sejrrige kampe. Derfor er det på dansk side værdsatte motiv med kampen ved Mysunde helt fraværende. Derimod blev der udført talrige billeder af de to mest spektakulære sejre, stormen på Dybbøl Skanser og kampen om Als. For selvom krigen i 1864 kun var den første af de tre tyske såkaldte foreningskrige, gav den alligevel anledning udførelsen af talrige billeder. Krigen mellem Preussen og Østrig i 1866 blev hurtigt vundet i løbet af få uger, og her var kun et enkelt større slag ved Königgrätz. I krigen med Frankrig 1870-71 var der ikke mange maleriske slagscener, hverken i forbindelse med erobringen af Sedan eller den langvarige belejring af Paris. Stormen på Dybbøl og den hasarderede, men vellykkede overgang til Als forblev derfor i en årrække populære motiver blandt tyske historiemalere. 
Historiemalerierne med motiver fra 1864 kan inddeles i fire grupper. Den første omfatter de danske og tyske billeder, der blev lavet i krigsåret og det første årti derefter. Det er situationsbilleder, præget af datidens patriotisme og jævnligt udført på bestilling af folk, der deltaget i de kampe, der skildres. Nogle af billederne er patosfyldte, mens andre har en særlig kvalitet ved den friskhed og autenticitet, der præger dem. Der blev i det første årti efter krigen udført flere historiemalerier i Preussen end i Danmark, men en betydelig del heraf er forsvundet i løbet af Anden Verdenskrig. Det gælder ikke blot for hovedparten af Wilhelm Camphausens1864-malerier, men også for andre fremtrædende malere som Georg Bleibtreu og Emil Hünten. ${ }^{5}$

Den næste gruppe finder vi især på dansk side. Det er billeder, der skabt med henblik på styrkelse af nationen. De danske billeder blev udført fra omkring 1880 og var nært forbundet med oprettelsen af Det Nationalhistoriske Museum på Frederiksborg Slot i 1878. Hovedformålet var med brygger J.C. Jacobsens ord at skabe »et Hjemsted for Folkets Minder «, udvikle historisk sans og »styrke Folkets Selvfølelse og moralske Kraft, hvortil et lille Folk som vort i høj Grad trænger. $\varkappa^{6}$ Historiemalerier med et heroisk anstrøg og monumentale portrætter af fremtrædende officerer blev et vigtigt middel til at realisere dette formål. 1864-krigens barske virkelighed var nu kommet så lang afstand, at mandsmod, udholdenhed og dødsforagt midt i det uundgåelige nederlag kunne blive populære motiver.

Interessen for historiemalerier med motiver fra den tabte krig svandt omkring 1900, men fik både på dansk og tysk side en lille genoplivning i 1914, hvor Erik Henningsen og Ludwig Dettmann udførte billeder i anledning af 50-års jubilæet. Den fjerde og sidste gruppe historiemalerier finder vi næsten udelukkende på dansk side. Det er nutidige kunstneres genfortolkning af motiver fra de klassiske 1864-malerier. De giver ofte en indirekte kommentar til den aktuelle udenrigspolitik. Det nyeste historiemaleri med motiv fra Dybbøl Skanser, udført i 2014 af Thomas Kluge, er i en kategori for sig. Inden for rammerne af en magisk, symbolsk realisme inddrager billedet kendte nationalhistoriske elementer, mens selve fortællingen er uheroisk. Fortid og nutid, virkelighed og fantasi indgår her i en symbiose. Det tyske modstykke hertil er Christopher Lehmpfuhls maleri, der ligesom Kluges har motiv fra slagmarken på Dybbøl, men alligevel falder det ikke umiddelbart indenfor kategorien historiemaleri. Det 
er plein-air billede, malet på stedet i skiftende vejrlig og med hastige, kraftige strøg for at fange essensen af det sete og oplevede. Fælles for de to nutidige billeder er en tolkning af 1864-krigens følger på langt sigt.

I historiemaleriets glansperiode i 1800-tallet var det idealiserende, nationalromantiske fremstillinger, der var dominerende, mens det $\mathrm{i}$ nutiden ofte er ironiserende og distancerende skildringer. ${ }^{7}$ Fælles for dem er, at de rummer et fængende, holdningsskabende fortælleunivers, der skildrer både fortiden og samtidens opfattelser.

\section{LITTERATUR}

Adriansen, Inge: »Krigen 1864 i dansk billedkunst«", Jens Ahlers (Hg.): Mennesker i Krigen 1864 - Menschen im Krieg. Schleswig-Holsteinische Landesbibliothek \& Museum Sønderjylland - Sønderborg Slot. Kiel 2014, s. 311-360.

Adriansen, Inge: »Thomas Kluge: Dybbøl 1864«, Dansk Noter. Temahefte om krig. Dansklærerforeningen for Gymnasiet og HF, 2015:1, s. 24-26.

Becker, Frank: Bilder von Krieg und Nation. Die Einigungskriege in der bürgerlichen Öffentlichkeit Deutschlands 1864-1913. München 2001.

Bigum, Martin: Min personlige kunsthistorie, 2014.

Bligaard, Mette: Fædrelandshistoriske billeder. Det Nationalhistoriske Museum på Frederiksborg Slot, 1978.

Eller, Povl: »Brygger J.C. Jacobsens plan over historiske fremstillinger til Frederiksborgmuseet«, Danske Magazin, 8 rk., 5 bd., 4 hf., 1989, s. 309-336.

Heiberg, Steffen: »Nationalt portrætgalleri eller nationalhistorisk museum«, Mette Bligaard (red.). J.C. Jacobsen og Frederiksborg. Det Nationalhistoriske Museum på Frederiksborg Slot, 1997, s. 56-71.

Heiberg, Steffen: Danske portrætter. København 2003.

Lauring, Palle: Billeder af Danmarks historie. Maleren, danmarkshistorien og maleriet. København 1972.
Lopdrup, Hanne: »J.C. Jacobsen og historiemaleriet«, Mette Bligaard (red.): J.C. Jacobsen og Frederiksborg. Det Nationalhistoriske Museum på Frederiksborg Slot, 1997, s. 34-55.

Lopdrup, Hanne: »Et kort ophold - et historiemaleri af Thomas Kluge", Carlsbergfondets Ärsberetning 1999, s. 96-105.

Lyngby, Thomas (red.): 1864. Krigen der forandrede Danmark. Det Nationalhistoriske Museum på Frederiksborg Slot 2003.

Manitz, Bärbel: »Die 6. Kugel: Deutsche Künstner im Krig von 1864" Jens Ahlers (Hg.): Mennesker $i$ Krigen 1864 Menschen im Krieg. Schleswig-Holsteinische Landesbibliothek \& Museum Sønderjylland - Sønderborg Slot. Kiel 2014, s. 241-310.

Manitz, Bärbel und Hans Günther Andresen: "Gemälde vom deutsch-dänischen Krieg 1864" "Jens Ahlers (Hg.): Mennesker $i$ Krigen 1864 - Menschen im Krieg. Schleswig-Holsteinische Landesbibliothek \& Museum Sønderjylland - Sønderborg Slot. Kiel 2014, s. 169-184.

Mentz, Søren: »Kunsten at fremstille en død helt«. Fortid og Nutid 2003, s. 243262.

Schepelern, H.D.: 1864 i danske billeder. Det Nationalhistoriske Museum på Frederiksborg Slot. 1964. 
Søndergaard, Sidsel Maria, Gerd Rathe og Jens Toft: Carl Bloch 1834-1890.
Museet for Religiøs Kunst og Øregaard Museum, 2012.

\section{NOTER}

1. H.C. Andersen i brev juli 1866 til maleren Carl Bloch efter at have udtalt sin glæde over Blochs maleri »Niels Ebbesen og Grev Gert«. Sidsel Søndergaard m.fl. 2012, s. 260.

2. Povl Eller 1989, s. 309.

3. Ifølge Christiansborg Slotsforvaltnings kartoteksinventar blev billederne udført til en mindeudstilling om krigen Industriforeningen april 1914. Efter udstillingen forærede komiteen bag den tegningerne til kongen, der overdrog til slotsarkitekt Thorvald Jørgensen til udsmykning i kongefløjen på det genskabte Christiansborg.

4. Politiken 21.7.2013.

5. Bärbel Manitz 2014, s. 308ff.

6. Povl Eller 1989, s. 309.

7. Det gælder dog ikke de nye historiemalerier fra Danmarks aktive krigsdeltagelse fra 1990'erne, der er udført på bestilling af Frederiksborgmuseet.

\section{Zusammenfassung}

Die historischen Gemälde mit Motiven von 1864 können in vier Gruppen eingeteilt werden. Die erste Gruppe umfasst Bilder aus dem Kriegsjahr und dem darauffolgenden Jahrzehnt. Sie sind vom Patriotismus gekennzeichnet und waren oft von Kriegsteilnehmern bestellt. Einige mit viel Pathos, andere frisch und authentisch gemalt. Die nächste Gruppe befindet sich hauptsächlich auf dänischer Seite. Diese Gemälde wurden um 1880 ausgeführt und waren mit der Gründung des Nationalhistorischen Museums am Frederiksborg Slot nah verbunden. Die harten Realitäten des Krieges konnten nun aus der Entfernung betrachtet werden mit beliebten Motiven wie Mannesmut, Ausdauer und Todesverachtung mitten in der unumgänglichen Kriegsniederlage.

Das Interesse an den historischen Gemälden vom verlorenen Krieg nahm um 1900 ab, wurde jedoch 1914 anlässlich des 50-jährigen Jubiläums kurz wiederbelebt. Die vierte und letzte Gruppe historischer Gemälde befindet sich meist auf dänischer Seite und besteht aus zeitgenössischen Interpretationen von Motiven der klassischen 1864Gemälde. Das neueste dänische Beispiel aus dem Jahr 2014 von Thomas Kluge trägt nationalhistorische Elemente, ist in seiner Schilderung aber ohne jeglichen Heroismus. Das deutsche Gegenstück von Christopher Lehmpfuhl enthält wie bei Kluge Motive von den Düppe- 
ler Schanzen, versucht aber plein-air mit kräftigen Pinselstrichen die Essenz des Erlebten einzufangen. Gemeinsam für die zeitgenössischen Bilder ist die Interpretation der Folgen des Krieges von 1864 auf längere Sicht. 